\title{
Interpretasi Makna dalam Iklan Youtube
}

\author{
Hasnur Ruslan ${ }^{1}$ \\ Haslinda $^{2}$
}

\author{
12Universitas Muhammadiyah Makassar
}

\begin{abstract}
Abstrak
Berdasarkan masalah yang diajukan dalam penelitian ini, yaitu tentang perubahan interpretasi makna dalam iklan youtube, maka bentuk penelitian yang digunakan adalah penelitian deskriptif kualitatif. Bentuk penelitian ini mampu mendeskripsikan secara teliti dan mendalam fakta-fakta yang diteliti, dalam hal ini bentuk perubahan makna iklan.Dengan kata lain, penelititan deskritif kualitatif bertujuan untuk mendeskripsikan secara nyata fakta-fakta yang diteliti. Hasil penelitian ini menyimpulkan bahwa perubahan Interpretasi makna dalam iklan youtube bersifat Ilokusi dan perlokusi karena iklan yang disajikan tidak hanya berfungsi untuk menginformasikan sesuatu namun juga untuk melakukan sesuatu. Interpretasi makna juga melahirkan efek bagi masyarakat penonton memiliki pengaruh besar pada masyarakat dan kebudayaan, didasarkan pada kenyataan bahwa iklan memiliki pengaruh pada perilaku individu, bahkan kesenjangan sosial. Iklan juga membuat seseorang menjadi materialistis, egois, dan gaya hidup yang konsumtif.
\end{abstract}

Kata Kunci: Iklan, Youtube, Makna

\section{Pendahuluan}

Bahasa merupakan salah satu alat untuk mengadakan interaksi antara manusia yang satu dengan yang lainnya. Jadi, bahasa tidak dapat dipisahkan dengan manusia. Dengan adanya bahasa, manusia dapat berhubungan dengan manusia lain yang akhirnya melahirkan komunikasi dalam masyarakat. Dalam dunia komunikasi, bahasa dan media memiliki hubungan yang sangat erat dan saling mengisi antara yang satu dan yang lain. Tanpa bahasa, tujuan utama suatu komunikasi tidak akan tercapai dengan baik.

Periklanan melayani banyak tujuan dan banyak pula pemakainya mulai dari perorangan hingga perusahaan besar yang memasang iklan seperti media cetak untuk memperdagangkan aneka produk kepada jutaan masyarakat. Supriyanto, (2008:19) mengemukakan bahwa iklan adalah promosi barang, jasa, perusahaan, dan ide yang harus dibayar oleh sponsor. Sponsor dalam hal ini merupakan perusahaan tertentu yang nantinya menjadi klien jasa promosi.

Berdasarkan pengertian di atas dapat ditegaskan bahwa bahasa yang digunakan dalam dunia periklanan adalah bahasa yang hemat, singkat, dan padat. Persyaratan itu dimaksudkan agar bahasa yang digunakan tidak terlalu berbelit-belit sehingga maksud yang hendak disampaikan dapat diterima oleh pembaca atau pendengar iklan tersebut. Akan tetapi, harus disadari pula bahwa adanya persyaratan tertentu seperti singkat dan padat, sehingga pembuat iklan membuatnya dalam wujud pendek.

Kesuksesan sebuah iklan sangat bergantung pada kemahiran penulis iklan dalam menyusun pesan-pesan penjualan melalui bahasa sebagai sarana medianya. Penulis iklan tentu saja harus bekerja sama dengan juru gambar dan ahli jenis huruf guna menghasilkan interpretasi iklan yang artistik. 
Pada dasarnya setiap iklan menampilkan produknya untuk menarik konsumen agar menggunakan produk yang ditawarkan dari iklan tersebut. Periklanan terus berkembang dari tahun ke tahun dalam percaturan industri dan ekonomi dunia.Periklanan telah merambah ke beberapa sektor baik dalam bentuk cetak, maupun dalam media elektronik. Dalam media elektronik periklanan sudah merambah ke media sosial dan youtube. Bahakan dalam media youtube sebagai pendapatan utamanya adalah dari iklan. Produsen barang dan jasa membayar royalty penayangan iklan diselah-selah konten yang ditayangkan.Media youtube saat ini sudah menjangkau seluruh kalangan masyarakat baik di kota maupun di desa dan mereka dapat dengan mudah memilih ragam informasi yang diinginkan sesuai dengan kebutuhannya khususnya iklan. Dengan media youtube, masyarakat dapat menerima informasi atau berita atau penawaran barang dan jasa dengan cepat. Sehingga youtube juga berfungsi sebagai alat penunjang dan pendorong terjadinya suatu perubahan yang besar dalam kehidupan masyarakat.

Media youtube ini telah menunjukkan eksistensinya melalui banyaknya jumlah instalan 5 miliar. Ini membuktikan cakupan penayangan yang sangat global.Eksistensi Youtube yang begitu getol dalam menyajikan informasi dalam bentuk video, khususnya periklanan. Penggunaan bahasa dalam periklanan menimbulkan fenomena kebahasaan yang menarik. Kekreatifan pembuat iklan dalam memilih dan menggabungkan kata-kata untuk mengiklankan produknya membuat iklan manjadi salah satu bahan kajian dalam ranah ilmu bahasa.

Suatu iklan produk biasanya membuat slogan. Slogan merupakan perkataan atau kalimat pendek yang menarik atau mencolok dan mudah diingat untuk memberitahu atau menjelaskan maksud tujuan dari isi iklan tersebut dalam kalimat yang singkat.Penyusunan dan pemilihan diksi serta ketepatan tanda baca dapat menjadi gaya atau kekhasan suatu bahasa iklan, sehingga lebih mengena kepada sasaran (receiver) tanpa mengurangi maksud dari tujuan pengiklanan itu sendiri contohnya dalam iklam produk sepeda motor Yamaha yang memiliki slogan:

"Yamaha Semakin di Depan"

Kutipan iklan di atas mengalami perubahan makna karena dalam arti "Semakin di Depan" itu dapat diartikan bahwa motor Yamaha jauh meninggalkan lawannya ketika motor Yamaha diadu cepat, tetapi bukan itu maksudnya, maksud dari slogan ini adalah sepeda motor Yamaha teknologinya jauh lebih unggul dibandingkan sepeda motor lain. Yamaha menggunakan slogan seperti itu agar slogan tersebut bersifat persuasif dan profokatif. Persuasif karena slogan ini dapat memengaruhi konsumen sedangkan provokatif karena slogan ini menjatuhkan produk sepeda motor lain. Ini sengaja dilakukan agar iklan tersebut dapat mendongrak penjualan sepeda motor ini.

Fenomena makna inilah yang akan melahirkan sebuah kajian dari hubungan antara bahasa dan konteksnya yang biasa disebut pragmatik. Perubahan makna suatu kata yang terjadi, kadang-kadang hampir tidak disadari oleh pengguna bahasa itu sendiri, salah satunya yaitu dalam proses periklanan. Oleh sebab itu penulis memilih meneliti penggunaan kalimat dalam proses periklanan di media Youtube, dan penelitian ini berjudul "Interpretasi Makna Dalam Iklan Youtube".

Dalam Kamus Besar Bahasa Indonesia, perubahan adalah (1) hal (keadaan) berubah; (2) peralihan; pertukaran (Depdikbud, 2005:1577). Sedangkan perubahan yang dimaksud dalam penelitian ini, yang merupakan ciri dan sifat bahasa yang dipaparkan oleh Kridalaksana dalam Konta (2000:33), bahwa yang merupakan hakikat dan ciri bahasa adalah bahasa itu bersifat dinamis, dengan sifat kedinamisan tersebut bahasa terus berkembang sesuai dengan perkembangan manusia. 
Perkembangan bahasa ditandai dengan semakin bertambahnya kosakata yang hadir di masyarakat pada setiap saat. Pertumbuhan kosakata akan sangat berpengaruh terhadap perkembangan makna. Perkembangan makna ini juga mengalami perubahan yang sesuai dengan kebutuhan. Tentang terjadinya perubahan makna tersebut, (Djajasudarma, 1993:141), menyatakan bahwa.

Selanjutnya, kata adalah kesatuan kumpulan fonem atau huruf yang terkecil yang mengandung pengertian (Alisjahbana, 1983: 44). Sedangkan menurut Azis (1993:163), kata adalah satuan bebas terkecil (a minimal free form).

Dari uraian di atas, dapat disimpulkan bahwa yang dimaksud dengan perubahan makna kata dalam penelitian ini adalah terjadinya perubahan arti atau maksud suatu kata bahasa Indonesia setelah berada dalam kalimat, sebab Badudu (1994:295) menyatakan bahwa setiap kata memiliki makna, baik makna leksikal, makna denotatif, atau makna konseptual. Namun dalam penggunaannya, makna kata itu baru menjadi jelas apabila kata itu sudah berada dalam konteks kalimat atau situasinya.

\section{Pragmatik}

Pragmatik sebagai salah satu bidang ilmu linguistik, mengkhususkan pengkajian pada hubungan antara bahasa dan konteks tuturan.Menurut Tarigan (1984:34) pragmatik merupakan telaah umum mengenai bagaimana caranya konteks mempengaruhi cara seseorang menafsirkan kalimat. Pendapat lainnya disampaikan Eriyanto (2001:21) bahwa seseorang tidak dapat mengerti benar-benar sifat bahasa bila tidak mengerti pragmatik, yaitu bagaimana bahasa digunakan dalam komunikasi. Pernyataan ini menunjukan bahwa pragmatik tidak lepas dari penggunaan bahasa.

Ohoiwutun (2007: 17) mengemukakan konsep tindak tutur ujar dalam suatu tuturan yang dikemukakan oleh Searle di dalam bukunya yang berjudul Speech Acts: An Essay in The Philosophy of language. Secara pragmatis setidak-tidaknya ada tiga jenis tindakan yang dapat diwujudkan oleh seorang penutur, yakni tindak lokusi (locutionary act), tindak ilokusi (ilocutionary act), dan tindak perlokusi (perlocutonary act).

\section{Tindak Ilokusi}

Chaer (1995:18-19) berpendapat bahwa tindak ilokusi adalah tindak tindak tutur yang mengandung maksud dan fungsi daya ujar. Tindak tersebut diidentifikasikan sebagai tindak tutur yang bersifat untuk menginformasikan sesuatu dan melakukan sesuatu, serta mengandung maksud dan daya tuturan.

Tindak ilokusi tidak mudah diidentifikasi, karena tindak ilokusi berkaitan dengan siapa petutur, kepada siapa, kapan dan di mana tindak tutur itu dilakukan dan sebagainya. Tindak ilokusi ini merupakan bagian yang penting dalam memahami tindak tutur.

Djajasudarma (1993:53) menyatakan bahwa tindak ilokusi adalah tindak tutur yang biasanya diidentifikasikan dengan kalimat performatif yang eksplisit. Tindak ilokusi ini biasanya berkenaan dengan pemberian izin, mengucapkan terimakasih, menyuruh, menawarkan dan menjanjikan.

\section{Tindak Perlokusi}

Djajasudarma (1993:53) menjelaskan tindak perlokusi adalah tindak tutur yang berkenaan dengan adanya ucapan orang lain sehubungan dengan sikap dan perilaku non linguistik dari orang lain. Sebuah tuturan yang diutarakan oleh seseorang seringkali mempunyai daya pengaruh (perlocutionary force), atau efek bagi yang mendengarkannya. Efek atau daya pengaruh ini dapat secara sengaja atau tidak sengaja dikreasikan oleh penuturnya. Tindak tutur yang pengutaraannya dimaksudkan untuk mempengaruhi lawan tutur disebut dengan tindak perlokusi. 


\section{Hakikat Iklan}

a. Pengertian Iklan

Otto Kleper, (1976:120) seorang ahli periklanan terkenal merupakan orang yang berjasa besar dalam mengkaji asal muasal istilah advertising. Dalam bukunya berjudul Advertising Procedure, dituliskan bahwa istilah advertising berasal dari bahasa Latin yaitu ad-vere yang berarti mengoperkan pikiran dan gagasan kepada pihak lain. Jadi pengertian seperti ini sebenarnya tidak ada ubahnya dengan pengertian komunikasi sebagimana halnya dalam ilmu komunikasi.

Kata iklan didefinisikan dalam Kamus Besar Bahasa Indonesia sebagai (1) berita pesanan (untuk mendorong atau membujuk) kepada khalayak ramai tentang benda dan jasa yang ditawarkan; (2) pemberitahuan kepada khalayak ramai mengenai barang atau jasa yang dijual dipasang di dalam media massa seperti surat kabar, televisi, radio dan lain-lain (Depdikbud, 2005:882).

\section{b. Realitas Sosial dalam Iklan}

Realitas dipresentasikan dalam iklan dengan menggunakan pencitraan atau simbolisasi makna tidak pernah melepaskan diri dari konteks sosial budaya dimana iklan berada. Hal ini karena iklan menggunakan preferensi masayarakat, juga keinginankeinginan serta kebutuhannya untuk kemudian diterjemahkan dan dipresentasikan dengan bahasa khusus. Pihak pembuat iklan selalu berusaha menerapkan strategi periklanan yang dimengerti dan ditangkap dengan mudah oleh khalayak.

Kajian mengenai realitas sosial dalam kaitannya dengan iklan menyatakan bahwa iklan bukan sebuah cermin realitas yang jujur, tapi iklan adalah cermin yang cenderung mendistorsi membuat jadi indah atau cemerlang, melebih-melebihkan sesutau dan melakukan seleksi-seleksi atas tanda atau citra itu tidak merefleksikan realitas sosial, tetapi menyatakan sesuatu tentang realitas. (Suyatno, 2006, 53).

Memangada hubungan yang kuat antara iklan dengan realitas atau setidaknya antara iklan dengan realitas kehidupan mesyarakat sehari-hari, tetapi iklan melakukan seleksiseleksi atas materi-materi dengan hati-hati, ada materi yang diambil tapi ada materi yang dihilangkan.

Iklan memang telah menjadi bagian dari masyarakat industru kapitalis yang begitu powerful dan sulit untuk dielakan. Ia mendefinisikan apa itu gaya, dan apa itu selera bagus, bukasebagaisebuah kemungkinan atau saran, melainkan sebagai sebuah tujuan yang diinginkan dan tidak bias untuk dipertanyakan.

\section{Metode Penelitian Jenis Penelitian}

Berdasarkan masalah yang diajukan dalam penelitian ini, yaitu tentang perubahan interpretasi makna dalam iklan youtube, maka bentuk penelitian yang digunakan adalah penelitian deskriptif kualitatif. Bentuk penelitian ini mampu mendeskripsikan secara teliti dan mendalam fakta-fakta yang diteliti, dalam hal ini bentuk perubahan makna iklan. Dengan kata lain, penelititan deskritif kualitatif bertujuan untuk mendeskripsikan secara nyata fakta-fakta yang diteliti. Hal ini sejalan dengan pendapat Sihombing bahwa penelitian deskriptif kualitatif mengarah pada pendeskripsian secara rinci dan mendalam mengenai potret kondisi tentang apa yang sebenarnya terjadi menurut apa adanya di lapangan studinya (2003: 111). 
Strategi yang digunakan dalam penelitian ini analisis isi. Analisis menekankan pada perubahan interpretasi makna kata yang terkandung dalam kalimat iklan untuk mendeskripsikan tentang bentuk, perubahan interpretasi makna yang paling dominan, dan efek bahasa iklan di youtube bagi masyarakat.

\section{Definisi Istilah}

Untuk memperjelas arah penelitian ini, maka perlu dijelaskan batasan istilah yang terdapat di dalam penelitian. Adapun istilah tersebut adalah:

1. Perubahan makna adalah sebuah ujaran yang mengalami perubahan makna dari makna ujaran dengan respon yang dihasilkan oleh pembaca.

2. Pragmatik merupakan telaah umum mengenai bagaimana caranya konteks mempengaruhi cara seseorang menafsirkan kalimat.

3. Ilokusi adalah tindak tindak tutur yang mengandung maksud dan fungsi daya ujar.

4. Perlokusi adalah tindak tutur yang berkenaan dengan adanya ucapan orang lain sehubungan dengan sikap dan perilaku non linguistik dari orang lain. Tindak tutur yang pengutaraannya dimaksudkan untuk mempengaruhi lawan tutur disebut dengan tindak perlokusi.

5. Kalimat iklan merupakan sebuah kalimat pemberitaan (untuk mendorong atau membujuk) kepada khalayak ramai tentang benda dan jasa yang ditawarkan.

\section{Data dan Sumber Data}

Penelitian ini menggunakan sumber data berupa tayangan video, yaitu video iklan di youtube. Rubrik iklan youtube dipandang peneliti merupakan iklan yang menarik karena menawarkan aneka produk seperti otomotif, elektronik, dan lain-lain. Iklan youtube dipilih sebagai sumber data karena selain bersifat nasional juga lekat dengan masyarakat karena hamper semua pengguna gawai memiliki aplikasi ini untuk menikmati tayangan video.

\section{Teknik dan Prosedur Pengumpulan Data}

Untuk mendapatkan data yang diperlukan dalam penelitian, digunakan beberapa teknik :

\section{Teknik Observasi}

Teknik pengumpulan data dalam penelitian ini adalah rekam dan mencatat. Salah satu teknik pengumpulan data yang bersifat noninteraktif adalah merekam-mencatat. Teknik rekam dan mencatat dipilih karena sumber data dalam penelitian ini berupa tayangan video iklan di youtube.

Data dalam penelitian ini berupa kalimat-kalimat iklan yang di dalamnya ditengarai terdapat kata-kata yang mengalami perubahan interpretasi makna dari segi pragmatik. Selanjutnya kalimat-kaimat tersebut dideskripsikan atau dituliskan dengan mendaftar atau mengurutkan mulai dari satuan bahasa terkecil. Penulisan data disertai pengkodean data (kode data). Selain itu, juga menuliskan tanggal dan bulan terbit dengan kode yang telah ditetapkan. Hal itu dilakukan untuk memudahkan dalam mengurutkan data. Kemudian data yang ditemukan yang ada dalam kalimat tersebut ditulis tebal dan miring untuk kemudahan dan kecepatan analisis data.

\section{Teknik Klasifikasi}

Teknik klasifikasi data artinya data yang diperoleh kemudian diklasifikasikan menurut individual yang mengungkapkan pengambilan data dengan cuplikan waktu yang dipilih dan dipandang tepat untuk pengumpulan informasi sesuai dengan permasalahan yang dikaji (Arikunto, 1993:56).

\section{Teknik Intropeksi}


Data-data yang ditemukan yaitu kalimat iklan yang mengalami perubahan interpretasi makna pragmatik diklasifikasikan, dicek keabsahannya sebelum dilakukan analisis. Teknik ini digunakan apabila terdapat data yang diragukan.

\section{Teknik Analisis Data}

Teknik analisis data yang digunakan dalam penelitian ini adalah model analisis mengalir atau flow model of analisis, mengingat karakteristik data dan pengumpulan data dalam penelitian ini. Sesuai dengan pernyataan Pena bahwa pelaksanaan analisis data pada penelitian kualitatif dapat dilakuan dengan model analisis mengalir (flow model of analisis) (1012: 18). Pengumplan data yang dilakukan dengan merekam dan mencatat dokumen sudah dilakuan sejak awal sebelum kegiatan pengumpulan data, yaitu sejak penulisan proposal penelitian. Kemudian proses reduksi data dilakukan pada saat pengumpulan data. Selain itu, juga dilakukan penyajian data dan penarikan simpulan atau verifikasi. Dengan kata lain, komponen-komponen penelitian tersebut masih menjalin dan tetap dilakukan sampai waktu pengumpulan data selesai dan berakhir pada proses penulisan laporan penelitian.

Ada empat komponen dalam model analisi mengalir, yaitu pengumpulan data, reduksi data, penyajian data atau disply data, dan penarikan simpulan atau verifikasi. Penjelasan dari tiap-tiap komponen tersebut dituliskan di bawah ini.

1. Pengumpulan Data

Pengumpulan data penelitian dilakukan secara cermat dan teliti sesuai dengan teknik pengumpulan data yang telah ditetapkan.

2. Reduksi Data

Reduksi data dilakukan pada sumber data yang telah dikumpulkan, yang sebelumnya data yang digunakan telah ditentukan yaitu dalam rubrik iklan saja. Dengan kata lain, data yang dianggap kurang atau tidak mewakili dalam penerapan teori yang ada akan direduksi atau tidak digunakan.

3. Penyajian Data atau Display Data

Data yang sudah direduksi selanjutnya disajikan dalam sebuah informasi yang memberi kemungkinan adanya penarikan simpulan dan pengambilan tindakan. Adapun data yang disajikan berupa kalimat-kalimat yang di dalamnya ditengarai terdapat kata-kata yang mengalami perubahan interpretasi makna.

4. Penarikan Simpulan

Penarikan simpulan secara sederhana sudah dilakukan sejak awal pengumpulan data. Simpulan akan semakin mantap dan berakhir pada waktu proses pengumpulan data berakhir. Simpulan perlu diverifikasi agar bisa dipertanggungjawabkan. Verifikasi dilakukan dengan penelusuran berkas data secara cepat karena dimungkinkan ada kekurangcermatan peneliti pada waktu penyajian data. 


\section{Hasil}

Berikut kutipan iklan youtube yang mengalami interpretasi perubahan makna dalam bentuk pragmatik:

\section{Penawaran yang Bersifat Keuntungan}

\section{a. Iklan 1}

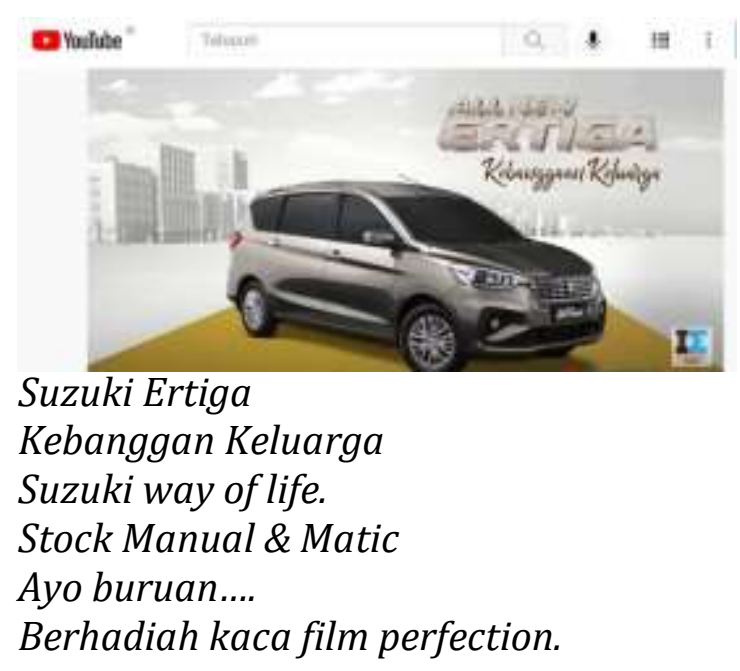

Iklan tersebut merupakan iklan penawaran bersifat keuntungan. Dalam hal ini dilakukan dengan asumsi bahwa pandangan memiliki latar belakang yang sama. Dengan memilih produk tersebut, konsumen diberikan hadiah kava film perfection. Inilah yang menjadi daya tarik dan dapat mempengaruhi pembaca untuk memiliki produk tersebut. Produk ini berasal dari satu perusahaan yakni Suzuki. Iklan ini menampilkan Ertiga maupun Vitara adalah mobil yang mempunyai kualitas dan mempunyai kelebihan baik dimesin dan desain yang dijadikan daya tarik bagi para pembaca iklan.

\section{b. Iklan No. 2}

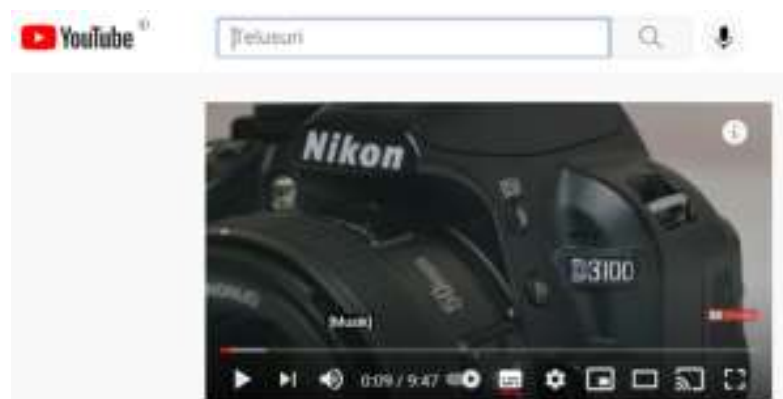

Kini saatnya dan memiliki kamera NIKON D-3100

18-55 $\mathrm{mml}$

Harga dibawah 6,5 juta rupiah....

Persediaan terbatas

Designed to take superior, high resolution pictures for everyone. 
Iklan No. 6 menunjukkan penawaran yang bersifat keuntungan. Menawarkan keindahan hasil dari foto dengan menggunakan 16 megapixel ini merupakan daya tarik untuk mencoba kamera Nikon 16 megapixel dengan desain yang menawan untuk memilikinya.

\section{c. Iklan 3}

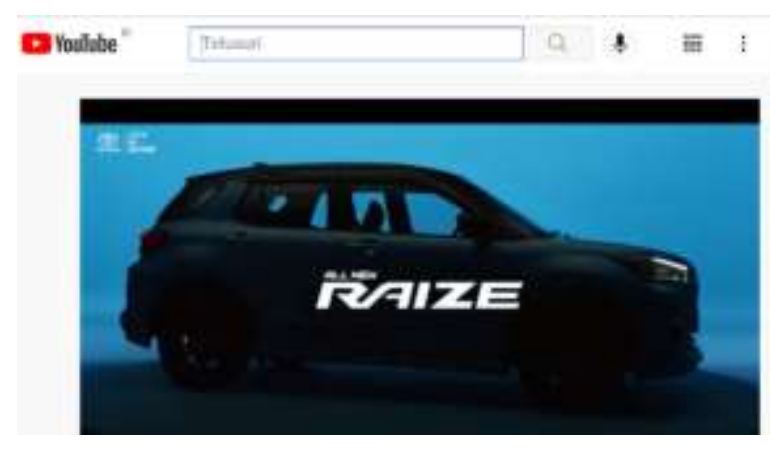

Toyota All New Raize!

Kesempatan terbaik miliki Toyota saat ini

PPnBM 0\%

Cash Back Puluhan Juta Rupiah dan Hadiah Bombastis!

Iklan ini memperlihatkan penawaran yang bersifat keuntungan. Iklan ini berusaha menyadarkan konsumen bahwa dengan memilih produk Toyota maka anda akan merasa puas karena kendaraan dengan banyak kelebihan juga banyak hadiah. Penawaran hadiah yang banyak dapat menarik perhatian konsumen memilih produk Toyota.

\section{Penawaran yang Bersifat Informasi}

\section{a. Iklan 1}

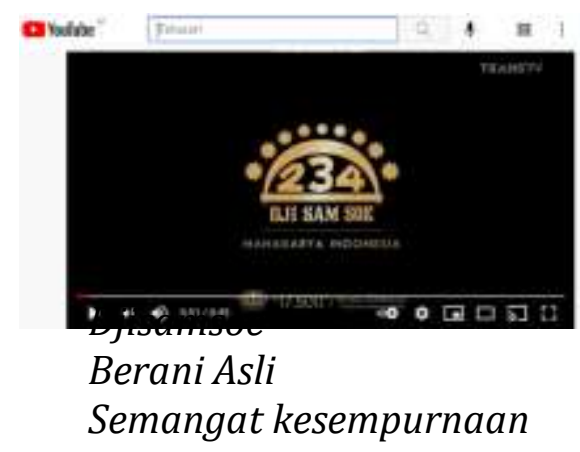

Iklan ini memperlihatkan penawaran yang bersifat informasi. Hal ini dilakukan dengan asumsi bahwa iklan ini memperlihatkan bahwa budaya juga memengaruhi dalam pemikiran rokok, terutama rokok Djisamsoe, dengan merokok Djisamsoe menimbulkan semangat kesempurnaan ini merupakan daya tarik bagi perokok atau pembaca yang membaca iklan. 


\section{Penawaran yang bersifat kemudahan}

\section{a. Iklan No. 1}

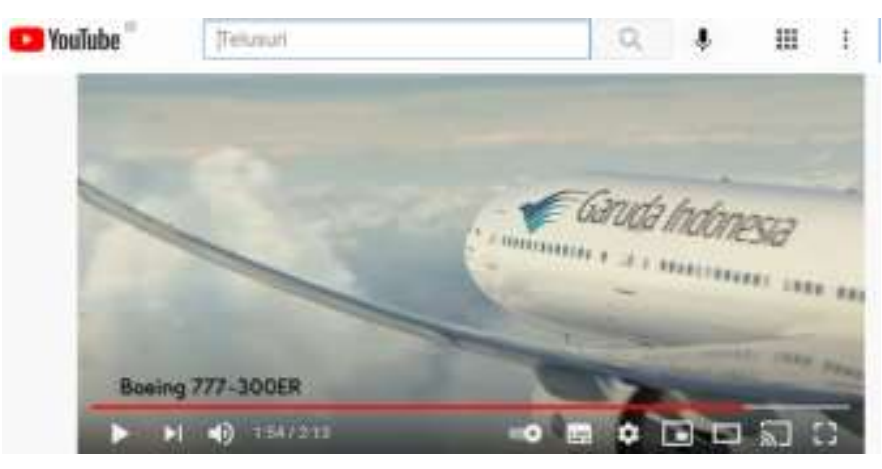

Dapatkan penawaran menarik.

Harga promo khusus

Mulai IRD 795.000

Harga belum termasuk tax,s fuels

Sure charge. Syarat kondisi berlaku.

Garuda Indonesia

Iklan ini menunjukkan penawaran yang bersifat kemudahan dan mengimformasikan pesawat Garuda Indonesia ini menawarkan harga promo, ini merupakan daya tarik dari iklan ini. Dengan menawarkan harga yang miring dan kelayakan terbang pesawatnya. Ini adalah daya tarik bagi pembaca iklan.

\section{b. Iklan 2}

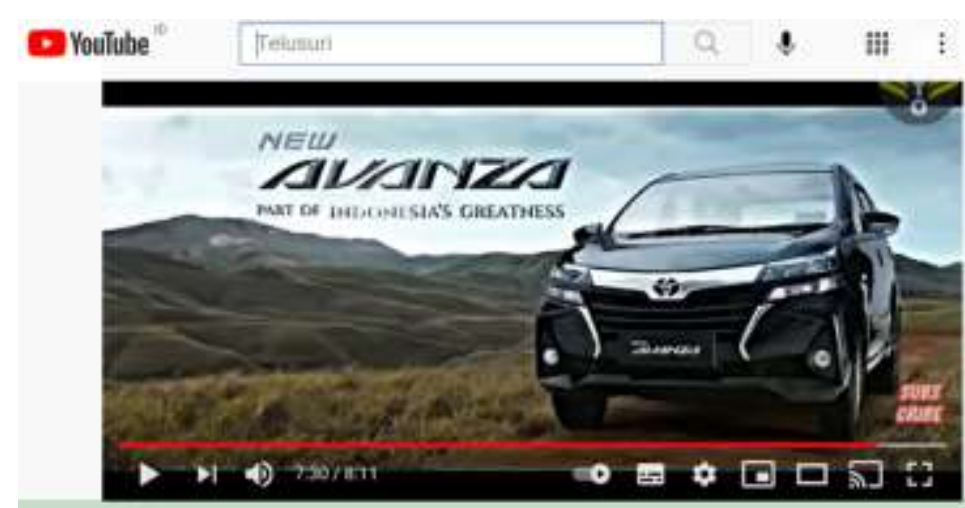

Toyota New Avanza

Datang dengan Mobil Lama

Pulang dengan Mobil Baru

Iklan ini menunjukkan penawaran yang bersifat kemudahan. Konsumen bisa dengan mudah memiliki mobil Toyota Avanza dan keuntungan yang diperoleh yakni anda 
datang dengan mobil lama maka anda bisa pulang dengan mobil baru karena kemudahan memiliki mobil ini.

\section{Penawaran yang Bersifat Keunggulan}

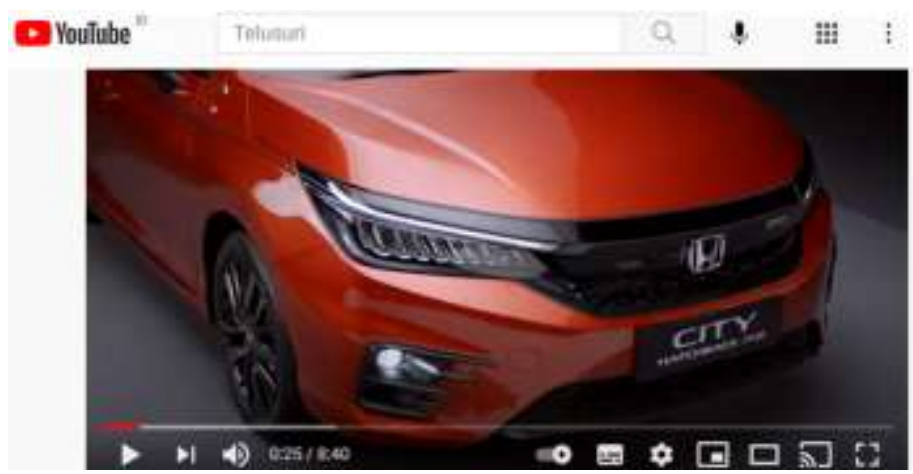

New Honda City

Elevate Your Move

New Honda City Hadir dengan desain hatchbackyang modern, lekuk garisnya semakin mempertegas karakter dan lebih baik dari Jazz

Hadir dengan paduan

Keseimbangan, keindahan, dan teknologi

Desain yang modern dan stylish interior

Yang mewah leluasa dan nyaman

Menjadi kebanggaan dalam menemani aktivitas anda.

Driving with style prestigious

Iklan ini menunjukkan penawaran yang bersifat keunggulan dan kecanggihan produk. Hal ini dilakukan dengan asumsi bahwa mobil Honda berdasarkan bingkai, mempunyai mesin yang baik dan desain yang menawan serta hadir dengan desain hatchback yang modern, lekuk garisnya semakin mempertegas karakter menawarkan kemewahan, menjadi kebanggaan dalam menemani aktivitas anda. Ini merupakan daya tarik dalam penampilan di kalangan pengusaha dan sekelasnya bagi pembaca iklan dan yang melihat langsung produknya.

\section{Pembahasan}

Temuan penelitian ini menunjukkan bahwa tidak semua makna mengatakan makna yang tersurat saja. Makna pragmatik terdapat dalam setiap iklan. Maka dari itu, perubahan makna kata terjadi dalam sebua iklan diakibatkan oleh penggunaan makna pragmatik. Perubahan makna itu terlihat dari segi bahasa iklan yang disajikan pada media youtube yang menyajikan bahasa iklan yang singkat tetapi memilki makna yang melenceng dari sebenarnya bahkan memiliki makna yang lebih luas. Sehingga iklan yang disajikan membuat pembaca memaknai sebuah iklan dengan mengandalkan daya nalar dan imajinasinya untuk memaknai iklan yang dia tonton. Ini diakibatkan karena iklan tersebut telah mengalami perubahan makna. Penggunaan bahasa pragmatik dalam iklan 
media yotube berkaitan erat dengan konsep psikologis penutur terhadap wacana yang mencakup latar pengetahuan, keyakinan, budaya dan harapan.

Tindak perlokusi adalah tindak tutur yang berkenaan dengan adanya ucapan orang lain sehubungan dengan sikap dan perilaku non linguistik dari orang lain. Sebuah tuturan yang diutarakan oleh seseorang seringkali mempunyai daya pengaruh (perlocutionary force), atau efek bagi yang mendengarkannya. Efek atau daya pengaruh ini dapat secara sengaja atau tidak sengaja dikreasikan oleh penuturnya. Tindak tutur yang pengutaraannya dimaksudkan untuk mempengaruhi lawan tutur disebut dengan tindak perlokusi. (Chaer, 1995:122).

Perubahan makna suatu kata yang terjadi, kadang-kadang hampir tidak disadari oleh pengguna bahasa itu sendiri, salah satunya yaitu dalam proses periklanan di media elektronik.

Iklan yang disajikan dalam media youtube semuanya mengandung ilokusi karena tuturan iklan yang disajikan semuanya mengandung tujuan dan maksud tertentu sehingga tuturan yang disajikan selalu berusaha agar tuturannya selalu relevan dengan konteks, jelas, dan mudah dipahami sehingga penenoton iklan dapat memahami maksud iklan yang disajikan.

Hasil temuan makna pragmatik iklan niaga youtube yang telah disajikan adalah:

1. Jasa telekomunikasi;

2. Kelebihan dan kecanggihan;

3. Keunggulan sebagai kelebihan;

4. Sebagai media penyampaian;

5. Kesuksesan;

6. Menawarkan kehematan;

7. Kuat dan cepat menghasilkan;

8. Menonjolkan sifat budaya pemberani dan tangguh;

9. Menonjolkan produk mutu;

10. Budaya atau jiwa petualangan;

11. Kecermatan sebagai keuntungan;

12. Kecanggihan;

13. Petualangan dan kesenangan;

14. Kemurahan dan kepuasan.

Dari 14 hasil temuan tersebut dapat diklasifikasikan menjadi 4 sifat penawaran yakni penawaran yang bersifat keuntungan, penawaran yang bersifat informasi, penawaran yang bersifat kemudahan, dan penawaran yang bersifat keunggulan. Untuk lebih jelasnya dapat dilihat pada tabel berikut:

Tabel 4.1 Kelompok Iklan Penawaran

\begin{tabular}{|c|l|c|c|}
\hline No. & \multicolumn{1}{|c|}{ Jenis Penawaran } & Jumlah Iklan & Persentase \\
\hline 1. & Bersifat keuntungan & 14 & $35 \%$ \\
\hline 2. & Bersifat informasi & 4 & $10 \%$ \\
\hline 3. & Bersifat Kemudahan & 5 & $12,5 \%$ \\
\hline 4. & Bersifat Keunggulan & 17 & $42,5 \%$ \\
\hline \multicolumn{2}{r|}{ Jumlah } & $\mathbf{4 0}$ & $\mathbf{1 0 0 \%}$ \\
\hline
\end{tabular}


Berdasarkan tabel di atas menunjukkan bahwa iklan yang terdapat pada youtube paling banyak terdapat iklan niaga yang menunjukkan penawaran yang bersifat keunggulan dan keuntungan. Banyak produsen yang menawarkan produk barang dan jasanya dengan memamerkan keunggulan produknya dan membandingkannya dengan produk lain. Makna pragmatik yang terdapat pada iklan youtube memiliki makna ilokusi dan perlokusi. Ilokusinya makna pada iklan di atas semuanya memiliki maksud, sedangkan perlokusinya membuat pembaca terpengaruh baik dari segi konsumtif, gaya hidupnya, dan membuat materialistis.

Makna pragmatik ini bertujuan agar produk barang dan jasa mendapat perhatian pelanggan yang akhirnya akan membeli produk barang dan jasa itu. Perlokusi yang dihasilkan sebuah iklan dapat mengalihkan pandangan pembaca yang sebelumnya barang yang diklankan tidak menjadi kebutuhannya tetapi setelah membaca iklan tersebut ini akan mengubah pandangannya yang tiba-tiba tertarik membeli produk tersebut. Jadi, efek yang ditimbulkan dalam iklan disebut perlokusi karena dapat mengubah pandangan pembaca. Kajian ini menunjukkan bahwa makna pragmatik paling efektif digunakan untuk menarik hati pelanggan. Sehingga pembuat iklan tidak bisa lepas dengan makna pragmatik dari iklan yang dibuatnya. Di sisi lain penggunaan makna pragmatik dapat menghemat penggunaan bahasa dalam iklan karena dalam satu konteks iklan dapat bermakna sangat luas dan mencakup semuanya tentang barang dan jasa yang diiklankan.

Sebenarnya, kontroversi sekitar persoalan efek iklan kian flamboyan karena cara penayangan Iklan yang etis. Ini seperti benang kusut pada masyarakat dan kebudayaan, didasarkan pada kenyataan bahwa iklan memiliki pengaruh pada perilaku individu, sosial bahkan kesenjangan sosial. Kekhawatiran umum terutama bersendi pada pendapat bahwa motivasi memperoleh keuntungan merupakan motif utama dari aktivitas periklanan yang dengan sendirinya akan menyebabkan manipulasi-manipulasi informasi dan menimbulkan kultur konsumtif.Selain itu, bahasa iklan tidak sekadar berupaya menarik perhatian masyarakat untuk membaca. Yang lebih penting, menggiring mereka untuk memiliki produk-produk yang ditawarkan. Iklan tidak menghimbau calon konsumen, tetapi konsumen diposisikan sebagai massa.

Secara kejiwaan iklan dapat memotivasi perilaku dan mengubah apa yang sebelumnya hanya sekadar keinginan (wants) menjadi kebutuhan (needs). Ini sejalan dengan hasil wawancara penulis dengan beberapa masyarakat mengatakan bahwa iklan yang ada di media elektronik khususnya youtube sangat mempengaruhi pola pikir masyarakat yang dulunya tidak ada niat membeli produk macam itu tetapi tiba-tiba ada keinginan membeli produk yang ditawarkan.

Selain mempunyai fungsi yang khas serta adanya dampak perubahan sikap pada masyarakat yang dulunya tidak mau membeli produk tersebut tiba-tiba mau membeli, Setiap informasi pada iklan bisa terekam dimemori penonton, sehingga setiap saat dapat diingat kembali. Kedua, menimbulkan perangkat mental, artinya setiap iklan yang ada penenton dapat mengerti makna yang ada pada setiap informasi diperlukan pemikiran perangkat mental yang aktif. Ketiga, pesan menyangkut kebutuhan komunikan, karena iklan youtube adalah media komunikasi satu arah, sehingga dalam penyampain informasinya dibuat semenarik mungkin. Keempat adalah efek sesuai dengan tujuan, 
setiap informasi iklan yang diberikan, diharapkan mempunyai efek kepada pembaca agar menjadi tahu berbagai informasi produk yang ditawarkan.

Karena itulah, menurut hasil wawancara saya bersama Pak Sunusi (Guru SMK) mengatakan sejatinya, iklan dalam youtube memiliki efek bagi penonton. Penonton akan berusaha keras memenuhi kebutuhannya meskipun di luar rencana pembelian atau hanya bersifat kebutuhan sekunder saja. Dorongan inilah yang memaksa masyarakat memikirkan bagaimana cara untuk bisa memiliki produk yang ditawarkan. Ini akan mempengaruhi pola konsumsi masyarakat yang akan lebih meningkat.

Apa yang dikatakan beberapa masyarakat bahkan lebih jauh lagi, iklan dapat menciptakan keinginan-keinginan baru dengan terus menerus mengarahkan hirarki kebutuhan konsumen. Kenyataan semacam itu dapat di lihat di media youtube yang memuat iklan yang tidak lagi sekadar wacana untuk mengkomunikasikan produk dan trend baru. Tetapi lebih berkembang menjadi bentuk tontonan. Maka, wacana produksi dan konsumsi di kota-kota besar seperti Makassar adalah sebuah teater konsumerisme, dengan Mal sebagai panggung katedralnya, iklan sebagai media komunikasinya, konsumen sebagai aktornya dan gaya hidup sebagai temanya.

\section{Simpulan}

Hasil penelitian interpretasi makna dalam iklan media youtube menyimpulkan bahwa perubahan Interpretasi makna dalam iklan youtube bersifat Ilokusi dan perlokusi karena iklan yang disajikan tidak hanya berfungsi untuk menginformasikan sesuatu namun juga untuk melakukan sesuatu. Iklan dalam youtube semuanya mengandung maksud dan tujuan. Maksud dan tujuannya adalah berusaha membujuk atau memengaruhi penonton agar beralih pandangannya terhadap produk barang dan jasa yang ditawarkan. Iklan yang disajikan menghasilkan 4 jenis penawaran yakni penawaran yang bersifat keuntungan, penawaran bersifat informasi, penawaran bersifat kemudahan, dan penawaran bersifat keunggulan. Interpretasi makna juga melahirkan efek bagi masyarakat penonton memiliki pengaruh besar pada masyarakat dan kebudayaan, didasarkan pada kenyataan bahwa iklan memiliki pengaruh pada perilaku individu, bahkan kesenjangan sosial. Iklan juga membuat seseorang menjadi materialistis, egois, dan gaya hidup yang konsumtif. Kekhawatiran umum terutama bersendi pada pendapat bahwa motivasi memperoleh keuntungan merupakan motif utama dari aktivitas periklanan yang dengan sendirinya akan menyebabkan manipulasi informasi dan menimbulkan kultur konsumtif. Bahkan lebih jauh lagi, iklan dapat menciptakan keinginan-keinginan baru dengan terus menerus mengarahkan hirarki kebutuhan konsumen.

\section{Ucapan Terima Kasih}

\section{Daftar Pustaka}

Alisjabana, S.T. 1983. Inilah Bahasa Indonesia yang Baik dan Benar. Jakarta: Gramedia.

Arikunto, Surharsimi.1993. Prosedur Penelitian. Jakarta: Rineka Cipta.

Azis, Abdul. 1993. Pembukaan Bahasa Indonesia. Jakarta: Rhineka Cipta. 
Badudu, J.S. 1994. Tata Bahasa Praktis Bahasa Indonesia. Jakarta: Bhrata Media.

Chaer, Abdul. 1995. Pengantar Pragmatik Bahasa Indonesia. Jakarta: PT Rineka Cipta.

Depdikbud. 2005. Kamus Besar Bahasa Indonesia. Jakarta: Balai Pustaka.

Djajasudarma, Fatimah. 1993. Pragmatik 1 Pengantar ke Arah Ilmu Makna. Bandung: PT Eresco.

Effendy, Onong Uchjana. 1993. Asyik Berbahasa Jurnalistik: Kalimat Jurnalistik dan Temali Masalahnya. Yogyakarta: Santusta.

Eriyanto. 2001. Analisis Wacana: Pengantar Analisis Teks Media. Yogyakarta: LkiS.

Keraf, Gorys. 1992. Tanya Jawab Ejaan Bahasa Indonesia untuk Umum. Jakarta: Gramedia Pustaka Utama.

Kleper Otto. 1976. Advertising Procedure. Wales. Cardiff Question.

Konta, Berger. 2000. Jurnalistik dan Masyarakat. Yogyakarta: Lkis.

Ohoiwutun, Paul. 2007. Language and Power: Exploring Political Cultures in Indonesia. London: Cornel University Pres.

Pena, Nur Sari. 2012. Prosedur Penelitian Teori dan Praktik. Jakarta: Bina Aksara.

Samsuri. 1990. Analisis Wacana. Malang: IKIP Malang.

Sihombing, P. 2003. Penelitian Pendidikan. Medan: Unimed.

Suyatno, M. 2006a. Strategi Perencangan Iklan Outdoor Kelas Dunia. Yogyakarta: Andi Offset.

Suyatno, M. 2006b. Strategi Perencangan Iklan Televisi Perusahaan Top Dunia. Yogyakarta: Andi Offset.

Tarigan, H.G. 1984. Pengajaran Pragmatik.. Bandung: Angkasa. 